Dewu, S., Bala, R., \& Kambuno, N. T. (2020). Differences of Preparation Examination Methods for the Number of Acid-Resistant Bacteria. JURNAL INFO KESEHATAN, 18(1), 59-67.

Jurnal Info Kesehatan

Vol.18, No.1, June 2020, pp.59-67

P-ISSN 0216-504X, E-ISSN 2620-536X

DOI: 10.31965/infokes.Vol18.Iss1.390

Journal homepage: http://jurnal.poltekeskupang.ac.id/index.php/infokes

R E S E A R C H

Open Access

\title{
Differences of Preparation Examination Methods for the Number of Acid- Resistant Bacteria
}

\author{
Sherly Dewu ${ }^{1 a^{*}}$, Rahmahsari Bala ${ }^{1 \mathrm{~b}}$, Norma Tiku Kambuno ${ }^{1 \mathrm{c}}$ \\ ${ }^{1}$ Department of Medical Laboratorium Technology, Poltekkes Kemenkes Kupang, Indonesia \\ a Email address: dewusherly@gmail.com \\ b Email address: rahmahsaribalarb@gmail.com \\ c Email address: norma.kambuno@gmail.com
}

Received: 20 March $2020 \quad$ Revised: 18 June $2020 \quad$ Accepted: 26 June 2020

\begin{abstract}
Tuberculosis is an infectious disease caused by Mycobacterium tuberculosis which transmission is sputum less micro-discharge issued by an infected patient. The examination of tuberculosis in acid-resistant bacteria is recommended by WHO using the Ziehl Neelsen method. The objective of this study is to determine the differences in the way the preparations were examined for the number of acid-resistant bacteria. This research is a cross-sectional design laboratory experimental research. The study was conducted in June-July 2018. The examination was conducted microscopically using the Ziehl Neelsen method. The inspection procedure is performed on direct preparations and indirectly checked. The results of the study conducted showed that there was no significant difference in the number of acid-resistant bacteria ( $\mathrm{p}$-value $=0.758$ ). It was concluded that the results of examining the number of positive acid-resistant bacteria in direct and indirect preparations examined did not affect the results of the number of bacteria on the microscopic examination of positive acid-resistant bacteria. It is recommended for further studies on the use of uniformed samples for the making of preparations using one of the samples at any time.
\end{abstract}

Keywords: Acid Resistant Bacteria, Direct Preparations, Indirect Preparations

\author{
*Corresponding Author: \\ Sherly Dewu \\ Department of Medical Laboratorium Technology, Poltekkes Kemenkes Kupang \\ Adi SuciptoStreet, Penfui-Kupang, Indonesia \\ Email: dewusherly@gmail.com
}

(CThe Author(s) 2020. This article is distributed under the terms of the Creative Commons Attribution 4.0 International License (http://creativecommons.org/licenses/by/4.0/), which permits unrestricted use, distribution, and reproduction in any medium, provided you give appropriate credit to the original author(s) and the source, provide a link to the Creative Commons license, and indicate if changes were made. The Creative Commons Public Domain Dedication waiver (http://creativecommons.org/publicdomain/zero/1.0/) applies to the data made available in this article, unless otherwise stated. 


\section{INTRODUCTION}

Infectious and non-communicable diseases continue to be a major problem in East Nusa Tenggara Province. The biggest diseases that are still the focus of the government are Malaria (Kristina, 2018), Tuberculosis (Kambuno et al., 2019, Sukartiningsih \& Gunawan, 2016), Filariasis (Irfan et al, 2018), Hepatitis B (Kambuno et al, 2019), Maternal and child mortality (Awang, 2017, Wedho, 2017), Stunting problems (Tenda et al, 2017, Boro, 2017). Tuberculosis is an infectious disease which transmission is sputumless micro-discharge issued by the patients of positive Basil acidic Resistant (Kementerian Kesehatan, R.I. 2016). Tuberculosis is caused by Mycobacterium tuberculosis and is an acid-resistant bacterium that has cell walls that are rich in peptidoglycan and lipids so that they cannot absorb dyes or are difficult to stain. This bacterium is rod shaped and is acid resistant so it is known as Basil Acid Resistant (Mirawati \& Lestari, 2017, Kambuno N.T \& Fanggidae, 2017). Tuberculosis has been around for thousands of years and remains a major global health problem (Friedent et al., 2014). In 2016, there were an estimated 10.4 million new cases of tuberculosis worldwide and 1.7 million people died from tuberculosis (Toolkit, 2018). 2017 and 2018 are historic years for global and national efforts to end TB in accordance with the 2030 Sustainable Development goals, WHO is targeting to reduce tuberculosis deaths by $90 \%$ and reduce incidence by $80 \%$ in 2030 (Kementerian Kesehatan, R. I. 2016).

Indonesia is the country with the second largest number of new cases in the world after India. $60 \%$ of new cases occur in 6 countries, which are India, Indonesia, China, Nigeria, Pakistan and South Africa. Thus, China, India and Indonesia accounted for $45 \%$ of global cases in 2016. Nigeria and South Africa each accounted for $4 \%$ of the global total (Friedent et al., 2014).

Based on Health Profile data for 2017 and 2018, the number of TB BTA+ has increased, which was in $2017 \mathrm{~TB}+$ sufferers in East Nusa Tenggara by $29.5 \%$ and increased in 2018 to $32.2 \%$ (Kementerian Kesehatan, R.I. 2018). An increase in TB BTA+ cases occurs in almost all islands in East Nusa Tenggara and the success rate of treating tuberculosis patients in East Nusa Tenggara has decreased from 83.0\% in 2017 to $71.8 \%$ in 2018 (Kementerian Kesehatan, R.I. 2019).

Examination of tuberculosis in BTA germs which is recommended by WHO is the Ziehl Nelseen BTA examination. The sample needed to conduct this examination is sputum. Despite of germs microscopic examination by Ziehl Nelseen's method, it can also be seen from the broad picture of radiological lesions of pulmonary tuberculosis patients, technique (PCR), Immunochromatographic Tuberculosis (ICT) Test and latex agglutination examination (Kambuno et al., 2019). According to research conducted by Triandini, et al, in 2019, there is also a relationship between the results of examination of acid-resistant sputum bacilli and a broad picture of radiological lesions of pulmonary tuberculosis patients. For the accuracy of the detection of Mycobacterium tuberculosis by PCR technique is the same as in the culture of TB bacteria, but the examination time by PCR technique is shorter than the bacterial culture technique (Jasaputra, et al., 2005). However, BTA examination results are better than PCR because the possibility of positive patients on positive BTA results is greater than the positive PCR results (Utami, et al., 2002). The ICT test in establishing TB diagnoses is still not good compared to BTA (Purba \& Manurung, 2016). In the examination of latex agglutination, there is a conformity with microscopic AFB with a Kappa value of 0.473 where based on the Altman scale the value of 0.473 Kappa indicates that the level of 
Dewu, S., Bala, R., \& Kambuno, N. T. (2020). Differences of Preparation Examination Methods for the Number of Acid-Resistant Bacteria. JURNAL INFO KESEHATAN, 18(1), 59-67.

agreement on the examination of latex agglutination with microscopic AFB in the sufficient category (0.41-0.60) (Damhuri et al., 2020).

Microscopic examination of sputum with germs stains is a simple, fast, inexpensive, and quite sensitive examination as an initial screening for early detection of tuberculosis (TB) cases (Putri, 2017). It is reinforced by the results of research conducted by Jasaputra, et al., in 2005 which said that the diagnosis of pulmonary TB can be made $100 \%$ based on clinical improvement and positive germs examination or culture of Mycobacterium tuberculosis.

Microscopic examination of TB sputum preparations can be done by the Ziehl Neelsen method using Carbol Fuchsin dye concentration of $0.3 \%$, where the concentration is the standard for microscopic examination of TB (Fihiruddin \& Inayati, 2015). The concentration of alcoholic acid used in the BTA staining of the Ziehl Neelsen method is very influential on the results of the BTA examination (Amelia, et al., 2019). During the process of heating or drying the preparations can be done indirectly by settling at room temperature $\left(20^{\circ} \mathrm{C}\right)$ and incubator temperatures $\left(50^{\circ} \mathrm{C}-70^{\circ} \mathrm{C}\right)$ where the preparations are still in stable condition and can be checked (Amelia, et al, 2019). This is reinforced by the results of a study conducted by Mirawati \& Lestari in 2017 by the title Effect of Fuchsin Carbolic Acid and Sputum Heating Before Preparation of BTA Staining Results.

Besides Ziehl Neelsen, there is Tan Thiam Hok and fluorochrome staining as an acid-resistant staining method for microscopic examination of sputum. Fluorochrome staining gives the highest sensitivity compared to 2 other coloring methods. However, because this method requires very expensive equipment so it is difficult to be implemented in health facilities with simple facilities. Therefore, the Ziehl Neelsen staining method is a fairly simple method choice and gives quite high sensitivity and specificity (Purba \& Manurung, 2016). It is also in accordance with the results of research by Suryawati, et al., (2018).

Factors that influence the examination of bacteria are fixation, discoloration of bacteria, substrate, and intensification of coloring and the use of cover dyes (Budiyanto, 2002). Decrease in color intensity or loss of red color from Ziehl Neelsen's staining on sputum germs preparations can also be caused by the long time to send sputum preparations to the laboratory (Fihiruddin \& Inayati, 2015).

The obstacle of BTA germ examination delays can be caused by the lack of health service personnel who are in accordance with their expertise, incomplete examination tools and materials and inadequate electrical factors such as what has happened in Primary Health Center of Ternate which is a remote institution with inadequate facilities especially in the laboratory field. Skills and knowledge are needed by laboratory assistants or health service personnel regarding germs microscopic examination that has been proven from the results of Putri's, R. N., study in 2012, and assessment standards with the International Union Association scale Lung Tuberculosis Disease or IUALTD (Girsang et al., 2006).

In the Primary Health Center of Ternate during laboratory tests that did not go well, one of which was the examination of Mycobacterium tuberculosis. In the Primary Health Center of Ternate, there are sputum samples suspected of having germs TB + from the patient, so that preparations are made immediately and fixed. The preparation works only up to the fixation process because the preparations will be collected and stored in the preparation box approximately a week due to the lack of facilities for microscopic examination of germs bacteria in the Primary Health Center and then sent to the primary health center of microscopic reference located across the island from the 
Primary Health Center of Ternate to continue the examination. The things that are possible so that the invalid results are the duration of storage which results when the results are done under a microscope, the germ observed seems unclear as in the color of cells that should be red on a blue background will fade or because of the length of storage so that it is contaminated with foreign objects or artifacts so that at the time of coloring, the foreign objects or artifacts are also colored and the time of observation looks like germs germ.

Research conducted by researchers has never been performed before and is different from similar studies. The researcher gave three different treatments to the preparation in the form of a 5-day inspection delay because it was adjusted to the conditions at the Ternate Primary Health Center. However, the research performed by Kalma \& Adrika in 2018 was to postpone the inspection of sedans for 24 hours. Based on the constraints, the researcher is interested in examining whether there is a difference between the examination method and the amount of AFB.

\section{RESEARCH METHOD}

The study was conducted at the Bacteriology Laboratory of Health Analyst in June-July 2018. This research is a type of laboratory experimental research with cross sectional study design (Kambuno N.T \& Fanggidae, 2017). Samples were taken from sputum in suspected TB pulmonary patients with accidental sampling technique. Total samples obtained were 20 samples of sputum patients diagnosed with pulmonary TB and visited the Laboratory of Prof. Hospital. Dr. W.Z. Johannes Kupang. Each sample is made into three preparations. The first preparations as preparations with treatment $A$ are preparations that are directly colored then directly counted the number of AFB. The second preparations as preparations with treatment B are preparations that have been fixed and colored but stored for 5 days in the preparation box, after which the BTA bacteria count is calculated. The third preparations as preparations with treatment $\mathrm{C}$ are preparations that have been fixed and then the preparations are stored for 5 days in the preparation box then colored and the amount of BTA is calculated.

Data normality test used the Shapiro-Wilk test, if the data is normally distributed, the data analysis can be used the One Way Annova test but if the data is not normally distributed, the data analysis test can be used the Kruskal Wallis test. This test is used to see the difference in the way of inspection with three treatments for the amount of AFB.

\section{RESULTS AND DISCUSSION}

Table 1.Distribution of BTA Germ Test Results with Three Treatment Tests for 100/LP

\begin{tabular}{crrr}
\hline Sample & \multicolumn{3}{c}{ Result/Number of Germs } \\
\cline { 2 - 4 } Code & Treatment A & Treatment B & Treatment C \\
\hline 01 & 16.120 & 18.671 & 18.867 \\
\hline 02 & 54 & 38 & 75 \\
\hline 03 & 15.974 & 13.567 & 14.192 \\
\hline 04 & 13.100 & 14.909 & 12.855 \\
\hline 05 & 61 & 36 & 58 \\
\hline 06 & 46 & 25 & 45 \\
\hline 07 & 15 & 31 & 24 \\
\hline 08 & 25 & 35 & 53 \\
\hline 09 & 9.882 & 12.428 & 14.501 \\
\hline 10 & 29 & 50 & 33 \\
\hline 11 & 21 & 26 & 21
\end{tabular}


Dewu, S., Bala, R., \& Kambuno, N. T. (2020). Differences of Preparation Examination Methods for the Number of Acid-Resistant Bacteria. JURNAL INFO KESEHATAN, 18(1), 59-67. https://doi.org/10.31965/infokes.Vol18.Iss1.390

\begin{tabular}{rrrr} 
& & & $\mid \mathbf{6 3}$ \\
\hline 12 & 27 & 78 & 22 \\
\hline 13 & 41 & 56 & 71 \\
\hline 14 & 21 & 46 & 24 \\
\hline 15 & 5.554 & 9.730 & 9.092 \\
\hline 16 & 4.115 & 4.799 & 7.138 \\
\hline 17 & 10.757 & 12.002 & 1.365 \\
\hline 18 & 10.636 & 11.943 & 13.214 \\
\hline 19 & 12.073 & 12.451 & 12.006 \\
\hline 20 & 9.301 & 11.447 & 11.998 \\
\hline
\end{tabular}

Table 1 shows that treatment $\mathrm{A}$ is a fixation that was directly fixed, colored and immediately examined. Treatment B is a preparation that has been fixed and colored but the preparation was stored in the preparation box for 5 days and then examined. Treatment $\mathrm{C}$ is a fixed preparation which was then stored in a preparatory box for 5 days then stained and examined.

Table 2. Distribution of Analysis Results of BTA Check Ziehl Neelsen Method in Preparations with A, B and C treatments using the Kruskal Wallis Test
Treatment Group
P value
Conclusion

\begin{tabular}{|c|c|c|}
\hline Treatment A & & There is no significant \\
\hline Treatment B & 0,758 & $\begin{array}{l}\text { difference between the } \\
\text { examination method and the }\end{array}$ \\
\hline Treatment $\mathrm{C}$ & & amount of BTA \\
\hline
\end{tabular}

Table 2 shows the value of $P$ value $=0.758$ ( $>>0.05)$. Thus, it can be concluded that there is no significant difference between the examination method and the number of AFB.

The data normality test of this study used the Shapiro-Wilk test which shows a $\mathrm{p}$ value of 0.000 in which $p$ value is less than 0.05 so it can be concluded that the data is not normally distributed, then the data analysis test used is the Kruskal Wallis test. This test is used to see the difference in the way of inspection with three treatments for the amount of AFB. Based on the results of the statistically analyzed research, it was found that there was no significant difference between the examination method and the number of AFB. It is evidenced by the $\mathrm{p}$ value of 0.758 where the $\mathrm{p}$ value is greater than 0.05 , which means there is no significant difference between the inspection method and the number of AFB. Thus, the results of examining the number of positive BTA bacteria in preparations by different means of examination did not affect the results of microscopic germs positive examination.

The results tested were taken from the amount of BTA/100 LP germ counts with three examination treatments that were tabulated and tested using the Kruskal Wallis statistical test. Three treatments given in this study were treatment A which was preparations that were directly colored and then immediately counted the number of BTA germs, treatment B was preparations that had been fixed and colored but the preparations were stored in the preparation box for 5 days then the number of BTA germs was calculated and treatment $\mathrm{C}$, that is, the preparations that have been fixed and then the preparations were stored for 5 days in the preparation box and then colored and the amount of BTA was calculated. The results of this study are in line with the results of research conducted by Kalma \& Adrika in 2018 that there was no significant difference in the amount of acid-resistant bacilli between sputum specimens were directly examined with sputum specimens that were delayed 24 hours. 
The sampling technique used in this study was accidental sampling so that the taking of sputum for making preparations used positive germs samples that are already available in the laboratory without grouping sampling in the morning during the time. The results reporting scheme refers to the IUALTD scale and the World Health Organization (WHO), which is reported negative BTA if no BTA is found in at least $100 \mathrm{LP}$, if 1-9 BTA is found in $100 \mathrm{LP}$, the amount of BTA found/100 LP is reported, reporting $1+$ results $(+)$ if $10-99$ BTA are found in $100 \mathrm{LP}$, reporting results $+2(++)$ if 1-10 BTA are found in $1 \mathrm{LP}$ that are inspected for at least $50 \mathrm{LP}$ and $+3(+++)$ results if more than 10 BTA are found in $1 \mathrm{LP}$ inspected at least $20 \mathrm{LP}$.

The examination showed that there was no significant difference or did not affect the number of germs because the preparations of the three treatments had previously been fixed. The fixation process aims to kill bacteria but not change the structure of the bacteria. The fixation process performed on Mycobacterium tuberculosis is by passing the preparation over a bunsen flame. Germs are very sensitive to heat, sunlight and ultraviolet light so that germs bacilli in fixed fixation die immediately due to heating and they directly adhere to the objec glass without changing the bacterial structure so that of the three methods although there is a suspension process for 5 days but does not affect the number of germs that have been fixed (Girsang, 1999).

The weakness of this study is that some of the samples obtained from the hospital contain more saliva than expected sputum, resulting in preparations that are of poor quality. When staining, BTA bacteria are less attached to the preparation so that it affects the calculation of the number of AFB.

Errors that are often found in laboratory tests of BTA can occur due to the storage of preparations that are not in place. Preparations should be stored in a box slide (box slide) to avoid fungi or other microbes that affect the quality of the results of the examination at the time of research, other things that affect no difference in results also because preparations that have been fixed or stained, directly stored in the preparation box (Chen et al., 2012). Storage of preparations in the box slide aims to avoid insects, heat, moisture and dust that can affect the quality of preparations and avoid the emergence of fungi and other microbes that can cover the BTA contained in preparations that will be disturbed when reading the results that become unclear (can be positive or false negative) (Budiharjo \& Purjanto, 2016).

Mycobacterium tuberculosis is a bacterium that causes tuberculosis (Sakamoto, 2012). Mycobacterium tuberculosis is often known as acid-resistant bacilli (BTA) because it has cell walls that are rich in peptidoglycan and lipids that are difficult to stain. The coloring that is widely used in developing countries to color Mycobacterium tuberculosis is by Ziehl Neelsen's staining because the cell walls are from acid-resistant and hard-to-stain bacteria so that the effect of phenol and heating is able to make the wax or fat layer penetrated the basic fuchsin paint then at the time of washing the wax layer and fat that is opened will close again and when washing with fuchsin acid alcohol color is not separated, whereas in bacteria that cannot stand acid will fade and take the blue color of methylen blue (Kotłowski, 2015).

Mycobacterium tuberculosis bacteria when viewed under a microscope with Ziehl Neelsen's staining will look long and red on a blue background. Mycobacterium tuberculosis is resistant to low temperatures so that it can survive for a long time at temperatures between $4^{\circ} \mathrm{C}$ to minus $70^{\circ} \mathrm{C}$, but these germs can be killed using heating temperatures of $60^{\circ} \mathrm{C}$ for 20 minutes, and they will also immediately die in wet heating at temperatures of $100^{\circ} \mathrm{C}$. If exposed to sunlight, culture of germs will die within 2 hours (Girsang, 1999). 
Dewu, S., Bala, R., \& Kambuno, N. T. (2020). Differences of Preparation Examination Methods for the Number of Acid-Resistant Bacteria. JURNAL INFO KESEHATAN, 18(1), 59-67.

\section{CONCLUSION}

From the examination results of the germs number on positive acid resistant bacteria, it can be concluded that there is no significant difference between the preparations that are directly examined with preparations that are not directly examined so that it does not affect the results of the number of germs on microscopic examination of acid resistant bacteria. For further research, it is recommended that the use of uniformed samples for the making of preparations using one of the samples occasionally.

\section{REFERENCES}

Amelia, R., Hadijah, S. and Nasir, M. (2019). Pengaruh Konsentrasi Asam Alkohol Terhadap Hasil Pemeriksaan Basil Tahan Asam Metode Ziehl Neelsen. Jurnal Media Analis Kesehatan, 10(2), 126-135. doi: https://doi.org/10.32382/mak.v10i2.1266.

Awang, M. N. (2017). Kajian Kematian Ibu berdasarkan Kategori ANC, Kategori Risiko Tinggi dan Rujukan Kasus Risiko Tinggi di Kabupaten Sumba Timur Tahun 2011-2015. JURNAL INFO KESEHATAN, 15(1), 110 - 125.

Boro, R. M. (2017). Assosiation Between Mother Knowledge Related Nutrition and Complementary Feeding Pattern with Nutrition Status of $6-24$ Months Children. JURNAL INFO KESEHATAN, 15(2), 317-332.

Budiyanto. (2002). Mikrobiologi Terapan. Malang: Universitas Muhammadiyah

Budiharjo, T., \& Purjanto, K. A. (2016). Pengaruh Penanganan Sputum Terhadap Kualitas Sputum Penderita TBC Secara Mikroskpis Bakteri Tahan Asam. Jurnal Riset Kesehatan, 5(1), 40-44.

Chen, P., Shi, M., Feng, G., Liu, J., Wang, B., Shi, X., Ma, L., Liu, x., Yang, Y., Dai, W., Liu, T., He, Y., Li, J., Hao, X., and Zhaoa, G. (2012). A Highly Efficient Ziehl-Neelsen Stain: Identifying De Novo Intracellular Mycobacterium tuberculosis and Improving Detection of Extracellular M. tuberculosis in Cerebrospinal Fluid. Journal of Clinical Microbiology, 50(4), 1166-1170.

Damhuri, P. O. et al. (2020). Kesesuaian Pemeriksaan Aglutinasi Lateks Dengan BTA Mikroskopis untuk Mengidentifikasi Pasien Tuberkulosis. Jurnal Kesehatan Andalas, 9(1), pp. 82-87. DOI: https://doi.org/10.25077/jka.v9i1S.1159.

Fihiruddin and Inayati, N. (2015). Konsentrasi Carbol Fuchsin Dan Waktu Penyimpanan Sediaan Hapusan Sputum +2 Hasil Pewarnaan Ziehl Neelsen. Jurnal Kesehatan Prima, 9(2), 1478-1485.

Frieden T.R, Brudney K.F, Harries A. D. (2014). Global Tuberculosis: Perspectives, Prospects, and Priorities. JAMA. 312 (14), 1393-1394. doi: 10.1001/jama.2014.11450

Girsang, M., Partakusuma, L. G., Leshiowati, D., \& Erna. (2006). Penilaian Mikroskopis Bakteri Tahan Asam (BTA) Menurut Skala International Union Assciation Lung Tuberculosis Disease (IUALTD) Di Instalansi Laboratorium Mikrobiologi RS Persahabatan Jakarta. Media Litbang Kesehatan, 16(3), 42-48.

Girsang, M. (1999). Kesalahan-Kesalahan Dalam Pemeriksaan Sputum BTA Pada Rogram Penanggulangan TB Terhadap Beberapa Pemeriksaan Dan Identifikasi Penyakit TBC', Media Penelitian dan Pengembangan Kesehatan, 9(3), 33-41.

Irfan I, Kambuno N. T, Israfil I. Factors affecting the incidence of filariasis in Welamosa village Ende district East Nusa Tenggara. Global Medical \& Health Communication. 2018 Aug 30;6(2):130-7. 
Jasaputra, D. K., Onggowidjaja, P. and Soeng, S. (2005). Akurasi Deteksi Mycobacterium tuberculosis dengan Teknik PCR menggunakan "Primer X" dibandingkan dengan Pemeriksaan Mikroskopik (BTA) dan Kultur Sputum Penderita dengan Gejala Tuberkulosis Paru. Maranatha Journal of Medicine and Health, 5(1), 7-14.

Kalma and Adrika. (2018). Perbandingan Hasil Pemeriksaan Basil Tahan Asam Antara Spesimen Dahak Langsung Diperiksa Dengan Ditunda 24 Jam. Jurnal Media Analis Kesehatan, 9(2), 130-135.

Kambuno, N. T., Senge, Y. H., Djuma, A. W., \& Barung, E. N. (2019). Uji Tuberkulosis Laten Pada Kontak Serumah Pasien BTA Positif Dengan Metode Mantoux Test. Jurnal Info Kesehatan, 17(1), 50-63.

Kambuno, N. T., \& Fanggidae, D. (2017). Identifikasi Bakteri Gram Negatif Galur Extended Spectrum Beta Lactamase Pada Ruang NICU RSUD Prof. DR. W. Z. Johannes Kupang. JURNAL INFO KESEHATAN, 15(2), 333-345.

Kambuno NT, Bessie MF, Tangkelangi M. Risk Factors of Intra-familial Hepatitis B Virus Transmission among Hepatitis B Patients in Kupang. Glob Med Heal Commun. 2019;7(2):150-5.

Kementerian Kesehatan, R. I. (2018). Profil Kesehatan Tahun 2017. Jakarta: Kementerian Kesehatan Republik Indonesia.

Kementerian Kesehatan, R. I. (2019). Profil Kesehatan Tahun 2018. Jakarta: Kementerian Kesehatan Republik Indonesia.

Kementerian Kesehatan, R. I. (2016). Profil Kesehatan Indonesia. Jakarta: Kementerian Kesehatan Republik Indonesia.

Kotłowski, R. (2015). A novel method of Mycobacterium tuberculosis complex strain differentiation using polymorphic GC-rich gene sequences. The Journal of Polish Biochemical Society and of the Polish Academi of Sciences, 62(2), 317-322.

Kristina, R. H. (2018). Screening Test penderita Malaria Dengan Gold Standar Uji Laboratorium Untuk Validasi Kasus Malaria Positif Di Wilayah Puskesmas Lewoleba Dan Puskesmas Waipukang Kabupaten Lembata, Propinsi Nusa Tenggara Timur Tahun 2016. JURNAL INFO KESEHATAN, 16(1), 164-177.

Mirawati, M., \& Lestari, E. (2017). Pengaruh Pemberian Karbol Fuchsin dan Pemanasan Sputum Sebelum Pembuatan Sediaan Terhadap Hasil Pewarnaan BTA. Jurnal Ilmu Dan Teknologi Kesehatan,5(1), 23-33. DOI: https://doi.org/10.32668/jitek.v5i1.59.

Purba, D., \& Manurung, D. B. S. (2016). Perbandingan Pemeriksaan Basil Tahan Asam Metode Direct Smear Dan Metode Imunochromatographi Test Pada Tersangka Penderita Tuberkulosis Paru Di UPT. Kesehatan Paru Masyarakat Dinas Kesehatan Provinsi Sumatera Utara. Jurnal Analis Laboratorium Medik, 1(1), 3237.

Putri, R. N. (2012). Analisis Keterampilan Petugas Laboratorium Puskesmas dan Rumah Sakit dalam Pembuatan Sediaan Dahak Pemeriksaan BTA Mikroskopis di Kabupaten Wonosobo Tahun 2012. Unnes Journal of Public Health, 1(2). DOI: https://doi.org/10.15294/ujph.v1i2.

Sakamoto, K. (201). The Pathology of Mycobacterium tuberculosis Infection. Veterinary Pathology, 49(3), 423-439, DOI: https://doi.org/10.1177/0300985811429313.

Suryawati, B., Saptawati, L., Putri, A. F., \& Aphridasari, J. (2018). Sensitivitas Metode Pemeriksaan Mikroskopis Fluorokrom dan Ziehl-Neelsen untuk Deteksi Mycobacterium tuberculosis pada Sputum. Smart Medical Journal, 1(2), 56-61.

Sukartiningsih, M. C. E., Laka, Y., \& Gunawan, Y. E. S. (2016). Pengalaman Keluarga 
Dewu, S., Bala, R., \& Kambuno, N. T. (2020). Differences of Preparation Examination Methods for the Number of Acid-Resistant Bacteria. JURNAL INFO KESEHATAN, 18(1), 59-67.

Sebagai Pmo Dalam Pengobatan Tb Di Puskesmas Nggoa Kabupaten Sumba Timur. Jurnal Kesehatan Primer, 1(1), 16 - 27.

Tenda, P. E., Lenggu, M. Y., \& Ngale, M. S. (2017). Uji Aktivitas Antibakteri Ekstrak Etanol Kulit Pohon Faloak (Sterculia sp.) Terhadap Bakteri Staphylococcus Aureus. JURNAL INFO KESEHATAN, 15(1), 227 - 239.

Toolkit, C. (2018). World TB Day 2018 Campaign. Moscow.

Triandini, N., Hadiati, D. E., Husin, U. A., Roekmantara, T., \& Masria, S. (2019). Hubungan Hasil Pemeriksaan Sputum Basil Tahan Asam dengan Gambaran Luas Lesi Radiologi Tuberkulosis Paru di Rumah Sakit Al Islam Bandung. Jurnal Integrasi Kesehatan \& Sains, 1(1), 87-91.

Utami, B. S., Harun, S., Ekowatiningsih, R., Yuwarni, E., Kurniawan, L., \& Aditama, T. Y. (2002). Uji Validitas Teknik PCR (Polymerase Chain Reaction) dan Pemeriksaan Mikroskopis Bakteri Tahan Asam sebagai Alat Diagnosis Penderita TB Paru di Rumah Sakit Persahabatan, Jakarta. Media Penelitian dan Pengembangan Kesehatan, 12(3),24-29.

Wedho, M. U. M. (2017). Pengaruh Faktor Sosial Budaya, Partisipasi Masyarakat, Dan Faktor Kebijakan Anggaran Pemerintah Daerah Terhadap Lompatan Penurunan Kematian Bayi Di Kabupaten Ngada Dan Kupang. JURNAL INFO KESEHATAN, 15(2), 397-416. 